\title{
LETTERS OF JAMES ANTHONY FROUDE
}

\section{EDITED BY RAYMOND M. BENNETT}

THE letters which form the basis of this article are a part of the Stanton Memorial Library at New Jersey College for Women and are a continuation of the Froude letters to Cluseret published in the Journal of December, 1947.

$\mathrm{I}$

$\mathrm{N}$ the spring of $\mathrm{i} 872$, while he was still editing Fraser's Magazine, James Anthony Froude received an article, "The Interview at Aubervilliers," from General Gustave Paul Cluseret, the notorious Franco-American adventurer. Following the acceptance of this article for publication in the April issue of Fraser's, Froude requested Cluseret to write an account of his participation in the Fenian uprising of $\mathrm{I} 867$. When Cluseret submitted his "My Connection with Fenianism," Froude was highly pleased. Its appearance in the July number was, in Froude's opinion, "a Sensation," one which called forth favorable reviews in the London Times and the Pall Mall Gazette. Froude believed that, because of this article, the Government, despite the sentence of contumacy which had been placed on him, would gratefully grant Cluseret permission to return to England. The following letters refer to Froude's efforts to gain this permission and to his further attempts to aid Cluseret. ${ }^{1}$

\section{VII}

To Cluseret

$$
\begin{aligned}
& 5 \text { Onslow Gardens } \\
& \text { July I9 }[1872]^{2}
\end{aligned}
$$

\section{Dear General Cluseret}

I send you the results of a request which I made to the Cabinet in your behalf. ${ }^{3}$ They hesitated for several days, and they have not

\footnotetext{
1 Theodore Stanton published portions of Letters X, XIII, and XV in "Some Froude Letters" in the Nation, LXXIV (1902), 505, and of Letters IX, XI, XIV in "Letters on Public Affairs; James Anthony Froude" in the Independent, LIV (1902), 18 I I-I2.

2 The date that Froude divested himself of his deacon's orders, following the passage of the Clergy Disabilities Relief Act.

${ }^{3}$ Accompanying this letter is the following note to Froude addressed from the House of Commons Library on July 18,1872 :

"I have shown your letter \& photograph to $\mathrm{M}^{\mathrm{r}}$ Bruce, and stated to $\mathrm{M}^{\mathrm{r}}$ Gladstone
} 
come to a resolution without reluctance. They feel deeply the good service which you have done in telling the Fenian story and I have little doubt that if in a few months you like to write to $\mathbf{M}^{\mathrm{r}}$ Gladstone yourself \& give him an assurance that he need entertain no uneasiness as to your presence in England he will remove his objection to your return.

I am afraid from the account at the Post Office that your last Packet of MS contained a letter, and that it has in consequence been returned to you.

Receiving as I do a good number of MSS. I have been obliged to lay down a general rule that nothing is to be left at my house on which the fine for an enclosed letter is surcharged. I wish I could have sent you a more satisfactory answer from the Government. If you have any personal acquaintances in England who can satisfy $\mathbf{M}^{\mathbf{r}}$ Gladstone on the points on which he feels uncertain you had better avail yourself of their services. I could say no more than that your letters and writings had greatly interested me in you. More than this of course I could not say.

Yours very faithfully

J A Froude

\section{VIII}

To Cluseret

My dear Sir

Kenmare River ${ }^{4}$

August 3 [ 1872$]$

I wrote to you a fortnight ago before I left London enclosing a letter from a member of the Government. They value the Fenian article as it was certain that they would. They will I do not doubt

what you say. The result appears to be that the Gov ${ }^{t}$. had better have no understanding whatever with General C.

"The letter \& photograph both tend to produce a feeling of good will,-but that is a different matter.

"Truly yours

"C P Fortescue"

The Rt. Hon. Chichester Samuel Fortescue (1 $823-98$ ), afterwards Parkinson-Fortescue, and Baron Carlingford, at this time was Chief Secretary for Ireland.

${ }^{4}$ Froude first occupied the house Derreen at Kenmare, County Kerry, Ireland, in the summer of 1869 . There he began writing his English in Ireland. 
withdraw in a short time their objection to your coming to England. For the present however they decline to make promises. If you have any personal acquaintances in England who would speak to $\mathbf{M}^{r}$ Gladstone now is the time for them.

The second part of your MS is probably at my house in London. $I$ am at present in Ireland and shall not return thither for three weeks. The first part so far as I can learn was returned to you from the Post Office because it contained a letter. The rules are very strict about this.

I am sorry that my absence from London has prevented me for so many days from receiving your letter from Belgium. The want of an answer may I fear have exposed you to some inconvenience.

\section{Very faithfully yours \\ $\mathrm{J}$ A Froude. \\ IX \\ To Cluseret}

Dear General Cluseret

Westcliff House ${ }^{5}$

Ramsgate

Sept 4 [1872]

I am sorry to have left your letter so long unanswered. I have been and am still absent from London and my correspondence reaches me irregularly. Your MS is, I suppose, in Onslow Gardens. If so it will reach me today or tomorrow. I have written to my Publisher $\mathbf{M}^{\mathbf{r}}$ Longman and recommended him to undertake the Publication. ${ }^{6}$ When I have his answer I will write to you again. If he consents he will place himself in direct communication with you. I sail myself for America on the $24^{\text {th }}$ of this month but I hope I shall see your matters in good train before I start.

I am strongly of opinion that you may safely come to England if you do nothing while here to alarm the Government. They are all very well disposed towards you. I do not know to what your friends refer when they speak of the attacks upon your Article. I have myself seen nothing but praise of it. Every influential person

${ }^{5}$ The home of John Ashley Warre, the father of Froude's second wife.

6 Presumably the MS was a portion of Cluseret's memoirs. 
of all shades of politics in England thanks you for it most heartily. Fenianism is dead. ${ }^{7}$ You have given it the coup de grace. The battle of the future will be over the land, and must be fought both in England \& Ireland. That is the point which I mean to work in my American lectures. ${ }^{8}$

\section{Ever faithfully yours}

$\mathrm{J}$ A Froude.

If Longman declines your book I will try some other House but I do not think he will decline it.

\section{$\mathrm{X}$}

\section{To Cluseret}

\section{Onslow Gardens Sept I I [ [ 872]}

\section{Dear General Cluseret}

Any account which you can give [to $]^{9}$ us of the circumstances connected with the Archbishop of Paris will be welcome to Frasers and, I think, to the English Public. ${ }^{10}$

In my absence you can write to W Allingham Esq ${ }^{11}$

\section{Neville Street \\ Brompton \\ London}

7 This sentence and the last two sentences of this paragraph were printed in the Independent, LIV, p. I8I . The Fenian Brotherhood was started in the United States in 1858 . In a manuscript letter in the Stanton Memorial Collection, James Stephens, writing from Brussels, August 26, I887, acknowledged himself as "the founder of the Fenian Brotherhood in the United States, \& of the Republican Brotherhood in Ireland." Fenian activities did not flourish in Ireland until 1865 , after the end of the war in this country. They came to a head in 1867 , when in February an uprising at Chester was quelled, and when in September and December efforts to free Fenian prisoners at Manchester and Clockenwell similarly failed.

${ }^{8}$ See Letter IV, footnote 25 , Journal, XI (December, I947), Ir.

${ }^{9}$ The manuscript reads of.

${ }^{10}$ In "Behind the Scenes at the Commune," published in Fraser's in December i8 72 , Cluseret gave his version of the imprisonment at Mazas of Archbishop Darboy and his sister, ordered by Raoul Rigault. Elihu B. Washburne, American Minister to France, appealed to Cluseret on the Darboys' behalf, and Cluseret was successful in freeing Mile. Darboy. See Washburne's account in his Recollections of a Minister to France, II, I 66-67.

${ }^{11}$ William Allingham ( $1824-89$ ), poet and essayist, was sub-editor to Fraser's from I 870 until 1874 , when he succeeded Froude as editor, a position which he held until 1879 . 
or simply to the Editor of Frasers at Messrs Longmans 39 Paternoster Row. This will perhaps be the safest address. I have not yet heard from $\mathrm{M}^{\mathbf{r}}$ Longman about your Memoirs. He will require, I think, to see the whole MS. before he makes up his mind.

As to your affairs with the Cunard Company. I can think of no one who will manage it better than $\mathbf{M}^{\mathbf{r}}$ Shaen, a solicitor of high Liberal reputation. I have written to him generally and I have told him that you will send him the exact particulars. His address is $\mathrm{W}^{\mathrm{m}}$ Shaen Esq

I 5 Upper Phillimore Gardens Kensington

London.

You ask about $\mathrm{M}^{\mathrm{r}}$ Bradlaugh. ${ }^{12} \mathrm{I}$ had never seen him, but $\mathrm{I}$ have heard much about him. He is one of those able eloquent men, who have large influences over the masses of thinking working men,but are particularly obnoxious to the Upper Classes of Society and therefore never succeed in making themselves a political force in the State. They start the ideas which in the end prevail. They agitatethey create the materials of a considerable movement. But as soon as the movement has attained dimensions enough to be important the leadership is taken out of their hands by one or other of the established parties in Parliament and they are themselves thrust aside.

Bradlaugh is reported to believe in the possibility of a violent Revolution in England, which he can himself lead \& control. I consider this to be the wildest illusion. The reverence for rich men is so

12 These final paragraphs appeared in the Nation, LXXIV, 505. Charles Bradlaugh (1833-9 $)$ began his long career as a republican and freethinker in the 1850 's. He was associated from 1860 on with the National Reformer, a weekly publication of which he became the proprietor in 1862 . He wrote the first draft of the Fenian proclamation of 1867 . Three years later he acted as a representative of English freethinkers to Castelar, the Spanish republican. At the beginning of the Paris Commune, he went to France to serve as an intermediary between the Communards and Thiers, but, following his arrest, he was returned to England. In 1874 he became associated with Mrs. Annie Besant, with whom he was arrested in 1876 for the publication of a pamphlet on birth control. Although sentenced and fined, he was able to have the conviction quashed. Repeatedly elected to Parliament for Northampton from i 880 until i $89 \mathrm{I}$, Bradlaugh was not seated until 1886 . When he sought to make an affirmation of his allegiance rather than to take the usual oath on the Bible, his endeavors started a long and deplorable controversy in Parliament. Even in 1885 when he agreed to take the oath, he was prevented from assuming his seat for another year. 
great in England that universal Suffrage \& the Ballot will only fill the House of Commons with Millionaires.

If trade failed and we had two or three millions out of employ with food at famine Prices we might have local disturbances, riots \& perhaps very great Political changes, but not even then such an alteration as would bring Bradlaugh to the front.

Yours most truly

J A Froude

XI

To Cluseret

Westcliff

Sept I8 [1872]

Dear General Cluseret

I have received your packet of M.S. and the letters of Introduction for which I am heartily obliged. ${ }^{13} \mathrm{M}^{\mathrm{r}}$ Longman tells me that he has written to you. I have forwarded the MS to him but I have taken the liberty of keeping back the English address to the "Shopmen." However applicable this may be to practices in France it is not generally applicable to England, and would if published with your name create a great deal of unfavourable $\&$ injurious criticism. I am sure that it would greatly prejudice "Longman" who is a representative great English tradesman,-but is popular and justly popular with those whom he employs.

As to the International. ${ }^{14}$ I regard its beginning like the beginnings of Christianity. It enunciates principles which in time will become the law of human society but centuries I suppose will elapse before those principles will have actively penetrated the mass of mankindor indeed before they will have assumed a shape in which they can work beneficially. Till then it will be an uphill fight with persecution, just as it was with Christianity. We witness now a convulsive revival of Catholicism, just as under the Roman Emperors there was a revival of Paganism, to meet the new ideas. All this shows that the Conflict will be a long one and I have more sympathy than you have

${ }^{13}$ Quite likely the letters to Fenian leaders in New York which Froude asked for in Letter IV.

14 This paragraph was printed in the Independent, LIV, p. 1811 . 
with authority, i.e. the Policeman, probably because in England we have too little of it instead of too much. Of course, it is essential that the authority should be just \& wise. This is the difficulty. But sooner or later you must come to that. The most stable Republics have been those in which the executive is vigorous while it lasts-but is liable to be called frequently to a strict \& severe account for the use of its powers. In Modern England our leading statesmen have little power $\&$ therefore little or no responsibility. In old England they had great power, but were liable to have their heads cut off if they abused it.

Your Journal will be very interesting \& valuable. I am the more sorry that I cannot at present mention any one to you who will advance money on the terms which you propose.

I have little connection with our so called Radical politicians in England. ${ }^{15}$ They represent at bottom the interests merely of the money makers. They do not and they never have cared heartily for the people. Their symbol of faith is "Political Economy" and Political Economy means that "the weakest may go to the wall." Political adventurers make themselves a name as patriots \& declaim on the peoples wrongs. As soon as they have pushed themselves into prominence, the upper classes buy them, and they kick away the ladder by which they have risen.

I have seen so much of this for so many years that I have ceased to interest myself in them or their proceedings. There are (or were) good Republicans in Manchester, Germans chiefly who are men of wealth. ${ }^{16}$ Your best chance would be among them, and if you have not found what you require when I return from America I will make enquiries.

I see you have a curious little Coining Drama unfolding in Switzer-

${ }^{15}$ This paragraph and half of the following were published in the Independent, LIV, p. I8I I, where they were incorrectly dated September II, I 872 .

${ }^{16}$ For many years, of course, Manchester had been the center of nineteenth century liberal and radical activities. Because of England's monopolistic control over the textile trade, many rich European dealers, especially Germans, set up mills or buying agencies in Manchester so that they could export cotton goods to their native countries. W. Gwyn Pilkington, "Manchester Merchants," The Soul of Manchester; edited by W. H. Brindly (Manchester University Press, 1929), p. 215. One of these concerns was that of Ermen and Engels, to which Friedrich Engels served as the family representative in Manchester from 1850 to 1860 and, following his father's death, as a partner until 1869 . Gustav Mayer, Friedrich Engels; trans. by Gilbert and Helen Highet (New York: Alfred A. Knopf, 1936), pp. 137, 170-71, 201. 


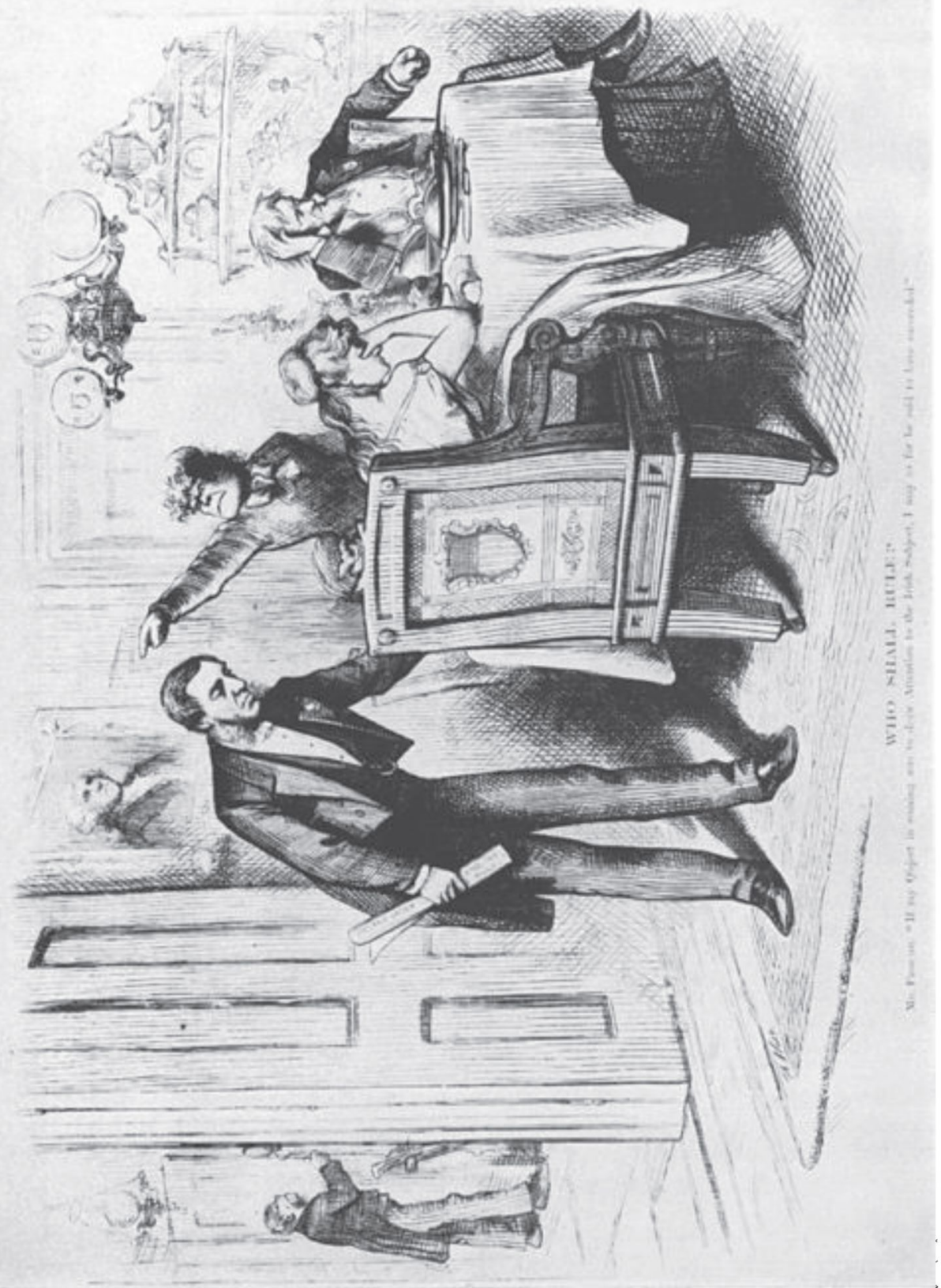

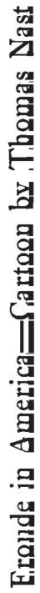


land. ${ }^{17}$ There appear to be "wheels within wheels" of villany. Let those who care ravel it out.

\author{
faithfully yours \\ J A Froude.
}

Having reluctantly accepted an invitation to lecture here, Froude spent the winter of $1872-73$ in this country. He arrived in Boston on October 6th and delivered a series of five lectures on the "Relations between England and Ireland" at the Association Hall (Y.M.C.A.) in New York City beginning October 16, 1872. An editorial in the New York Daily Tribune of October I 7 stated that Froude's addresses would "form an epoch in the history of the American platform," but that his thesis "that the misfortunes of Ireland are rather due to the congenital qualities of race than to wrongs inflicted by their conquerers" would also "excite earnest and perhaps bitter controversy."

Even before he finished his series, Froude had met opposition; on October 23, the Reverend Thomas Burke, O.P., speaking in Newark under the auspices of the New-Jersey Catholic Temperance Union, replied to Froude, and in November he declared himself more openly against Froude's interpretation of the Irish problems. To these criticisms, Froude responded in a New York lecture on November 30. He delivered his talks on Ireland elsewhere in this country, but, according to Paul, as was noted in the Journal, XI (1947), I I, footnote 26 , his life "was in danger, and he was put under special protection of the police," and his tour of the West was curtailed because of "Irish hostility." Following his stormy experience in the United States, Froude returned to England in February or early March, I873.

${ }^{17}$ This seemingly refers to difficulties in the Latin Monetary Union, composed of France, Italy, Belgium, and Switzerland. In this union, founded in 1865 , the members agreed to the double standard of gold and silver in the mint ratio of I5.5 to r. According to this agreement, in which the French, Belgian, and Swiss franc and the Italian lira had a gold parity of 19.3 cents, international trade was expedited. But by I 873 this bimetallic system had suffered several setbacks; the value of silver began to depreciate so steadily that France and Belgium were forced to restrict the free coinage of silver. At a convention called by Switzerland in 1874 , the members of the Union decided to limit the number of five-franc pieces to be coined. "Finally, in 1878 , the coinage of these silver pieces was discontinued. It was but a short step then to the adoption of the gold standard." Russell Donald Kilborne, Principles of Money and Banking (New York and London: McGraw-Hill Book Co., 1932), pp. 38-39. 
XII

To Cluseret

5 Onslow Gardens
London
March 28[1873 $]^{18}$

\section{My dear General Cluseret}

I am sorry to be obliged to confirm what I asked $\mathrm{M}^{\mathrm{r}}$ Allingham to communicate to you,- - being myself unwilling to be the first bearer of unwelcome news. ${ }^{19}$ You pay the price of fame in being formidable even to the readers of an English Magazine,-and not to the readers only but to the Proprietors whose wishes I am obliged to consult.

Some months hence when the alarm has subsided I will make room for another article from you (if you are then kind enough to offer me one). The objections to your being a regular contributor are decided, and I am obliged to suspend \& return those Papers which you have recently sent.

You have too much experience of the world to be at a loss to understand what this means \& will attribute no more importance to it than it deserves. The Fortnightly will I am sure take your contributions \& will pay you for them handsomely. ${ }^{20}$

We are on the edge I think of a Conservative reaction in England -I am not sorry. ${ }^{21}$ The Liberal party so far has been the party of

18 After Froude's return from the United States.

19 What this news was must be conjectured. Cluseret may have asked to be a regular contributor to Fraser's, or he may have offended Longman by one of his articles. His paper on "The Paris Commune of 1871: Its Origin, Legitimacy, Tendency, and Aim" appeared in Fraser's for March 1873 . In this work Cluseret concluded: "I think I have clearly demonstrated-( 1 ) That the Commune took its origin from the multiplied grievances which the working class had against the bourgeoisie, or directing class; ( 2 ) that its legitimacy flows from the facts, as well as from the primordial and imprescriptible right every man possesses, to derive, not only his subsistence, but also human happiness, from his labour; (3) that the aim of the Commune was simply to do for the proletariat what the bourgeoisie did for itself, in $7_{7} 89$-to found its admission to social power.

"The question is put (posée), and its success is certain, or both the Republic and universal suffrage will disappear. Universal suffrage, in consecrating the sovereignty of the individual, has necessarily consecrated the sovereignty of the group, or 'Commune,' the essential basis of the 'Republic'; which is a matter that concerns all.

"The future belongs to us. Defeated yesterday, we may conquer tomorrow. . .."

${ }^{20}$ Cluseret's "Military Side of the Commune" appeared in the Fortnightly in July, August, and September, 1873, XIV, I-24, 21 3-33, 350-70.

21 This paragraph was published in the Independent, LIV, p. 1812. Five days after this letter, April 2, I873, Froude similarly wrote to Skelton: "I am one of the weak- 
the men of money who to the poor are worse tyrants than the men of birth. Both will go down in the future but when all is said, you cannot have equality when Nature has made inequality. Wise \& brave men must lead, fools must follow, and submit to be led.How many centuries will have to pass before a new organization takes the place of the old, and the right men are in the right place?

\section{Yours faithfully \\ $\mathrm{J}$ A Froude}

\section{XIII}

\section{To Cluseret}

5 Onslow Gardens

October I9 [ [ 873 ]

\section{Dear General Cluseret}

I will gladly take from you the article on Genevan affairs which you propose to write. ${ }^{22}$ Meanwhile on the more important matters,

minded beings who are carried away by the Conservative reaction. Rather I see plainly that G[ladstone] is driving the ship into the breakers." Skelton, Table-Talk of Shirley, p. I 52. On March 12, 1873, Gladstone's Irish University Bill was defeated in its second reading, being opposed by both Protestants and Catholics, as well as by educationists, and the Irish Rule party. When Disraeli refused to form a ministry, Gladstone returned to office. The by-elections in the autumn resulted in the loss of Liberal seats. The Letters of Queen Victoria, second series, 1862-1878; edited by George Earle Buckle ( 2 vols.; New York: Longmans, Green \& Co., 1926), II, 233.

22 Cluseret published two articles in Fraser's on this subject: "The Religious Question in Switzerland" (February 1874) and "The Old Catholic Movement in Western or 'Romande' Switzerland" (March and April I 874). The first of these concerns the attempts to set up the Catholic establishment of Geneva in $1813-24$, and the efforts of Curé Vaurin to raise Geneva into a bishopric and to introduce the Brethren of the Christian Doctrine for the education of children. In the second article, Cluseret began with an account of the banishment from Switzerland of Bishop Merillod in 1873. Then follows a sketch of the career of Père Hyacinthe (Charles Loyson, r827-1912), who as a Carmelite became a sensational preacher in Bordeaux and Paris. In I869 "he threw away his gown" and later came to New York, where in the French theatre he preached "to an audience at so dollars a head." Loyson opposed a separation of the Church and State, wished to remain a reformed Catholic, and denounced the doctrine of Papal Infallibility. Cluseret concluded the March installment with the admonition: "Let them [the Old Catholic leaders] tell us in what their Christianity-Catholic or not is of little moment-is most in accord with the exigencies of modern society, with the spirit and conscience of mankind in $1874 . "$

In April Cluseret continued to explain how religious issues had caused serious difficulties in Switzerland, particularly the dissolution of the Sunderbund, established by the Catholic cantons in 1846 . Further disturbances arose in 1864 , when Bishop Mer- 
I have communicated your wishes to the Minister at $\mathrm{War},{ }^{23}$ and I sincerely hope that he may accept your services. The Cabinet ought to feel that they owe you something for your Paper on the Fenians, and I know them to be generally well disposed though so weak that we can expect nothing from them which they fear may rouse opposition. This cowardice is the curse of Constitutional Governments. We can only hope that they save us from what would be worse under other forms.

You shall hear from me as soon as ever I receive $\mathbf{M}^{\mathbf{r}}$ Cardwell's answer. I have asked that he should allow you to come to England and speak with him:- several days may elapse before I shall be able to write. $\mathrm{M}^{\mathrm{r}}$ Cardwell is in Scotland with the Queen and he may wish to communicate with his colleagues.

The accounts from France to day show that the reactionaries are bolder than you suppose. ${ }^{24}$ The Catholic Priests with the Pope at their head are delirious with vanity. They have three quarters of the French women at their backs. They have persuaded themselves that the Virgin Mary has taken to politics, - and in this state of mind may dare anything.

If as is possible they succeed in once more kindling a conflagration

millod was made Bishop of Hebron. The doctrine of Papal Infallibility was also subjected to bitter attacks throughout Switzerland. The proposed revision of the Swiss Constitution was to require all ecclesiastics to take the oath of submission to the State. Finally Cluseret stated: "Everywhere 'Old Catholics' are taking the place of Ultramontanes, and the schism is assuming the proportions of the Reformation; ... What at present may be foreseen is the formation of a National Swiss Church. This Church will without doubt be declared schismatic by Rome, but in giving the hand to the Old Catholics of Germany, to the Churches of the East, and to the Anglican Church, she may cease to be isolated."

${ }^{23}$ This paragraph and the third and fourth appeared in the Nation, LXXIV, 505. According to Froude's letter of May I4, I874, Cluseret was seeking a military appointment in India. The Secretary for War at this time was Edward Cardwell (18 13 86), later Viscount Cardwell.

${ }^{24}$ When Thiers resigned as president in May 1873 , a coalition replaced him with MacMahon. The Fusionist Monarchical Party tried to call an early meeting of the National Assembly in October to restore a constitutional monarchy to be headed by Henri Dieudonne Bourbon, Duc de Bordeaux and Conte de Chambord as king. On

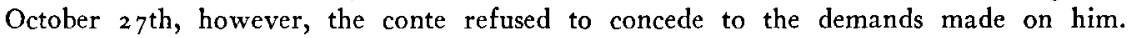
Consequently when it finally convened on November $5^{\text {th }}$, the National Assembly voted to re-elect MacMahon for ten years and to extend his powers. MacMahon's government, essentially one of negation, refused to allow the Republic to come into power and to curb the power and activities of the clergy. See the London Times for October and November 1873 . 
in Europe, it will be the beginning of the end. The whole system will be torn up by the roots. For this consummation I devoutly pray.

Meanwhile I remain yours

\section{faithfully \& with great esteem}

$\mathrm{J}$ A Froude.

\section{XIV}

\section{To Cluseret}

\section{Onslow Gardens \\ October 25 [1873]}

\section{My dear General Cluseret}

I regret to tell you that my application has failed. ${ }^{25}$ Our Government is called Radical. It is a Government of the Bourgeoisie, and you know what that means. It gathers its inspiration from the Shopkeepers, it regulates its actions by what will please the Shopkeepers. I could wish that some one else had made the proposition for you instead of myself,-but from the tone of the answer I do not think that any one would have succeeded. Next to the Shopkeepers the Cabinet desires most to please the Catholic Priests. ${ }^{26}$ You are not in favour with either of those classes; nor will they risk the outcry which would be raised were it known that you had been employed.

For myself, as I have told you, I despair of any good coming from "the people" in this country. The wider we make the Suffrage, the more entirely, Parliament becomes filled with merely rich men.

I prefer the Aristocracy to the Plutocrats. There will probably be a change of administration in the Spring, $-^{27}$ and though I cannot of course do more than express my opinion, I should think (so far at least as your coming to England is concerned) that $\mathrm{M}^{\mathrm{r}}$ D'Israeli would be more likely to consent to it than $\mathrm{M}^{\mathrm{r}}$ Gladstone. ${ }^{28}$

${ }^{25}$ All of this letter except the fourth and fifth paragraphs was published in the Independent, LIV, p. 1812 .

${ }^{26}$ Concerning the increased prestige of Roman Catholics on English Liberalism, Froude wrote in his life of Disraeli: "The Liberals who advocated that great measure [Catholic Emancipation], historians, statesmen, and philosophers, broke with the principle of which their predecessors had once been the staunchest advocates; changed front, and traduced the Reformation itself, to which Liberalism owed its existence." Lord Beaconsfield, p. 203.

${ }^{27}$ A Conservative ministry was formed by Disraeli in February 1874 .

${ }^{28}$ Disraeli was familiar with the career of Cluseret, for according to various authorities he patterned his character of the Garibaldian chief, Captain Bruges, in Lothair 
I am greatly vexed that I have no better news to communicate.

As to your Article on Swiss affairs I have as little belief in Pere Hyacinthe than yourself. But he has declared war against the Pope, -and in the interest of the general cause I do not look too curiously at my allies.

I cannot expect you to share my respect for Bismarck. ${ }^{28}$

Ever sincerely yours

$\mathrm{J}$ A Froude.

\author{
$\mathrm{XV}$ \\ To Cluseret \\ 5 Onslow Gardens \\ London \\ May I4 $[1874]^{30}$.
}

\title{
Dear General Cluseret
}

I have read your letter with great interest. I sympathize with you, and will do everything in my power to help you. I know well how bitter it is for a man of ability and accomplishments, conscious of talent, and of a desire to use his life nobly, to be cast aside in compelled inactivity. I am assured that you are sincere in your wish to be of use in your generation, as I am assured also that you have been sincere throughout your career.

But as to your present proposal.

The Conservative Cabinet now in office ${ }^{31}$ is composed of two sec-

( 1870 ) after Cluseret. In a letter to Skelton dated May 3, 1878 , Froude referred to "the tenderness with which the 'General' is treated in Lothair, . .." Skelton, Table-Talk of Shirley, p. 157.

${ }^{29}$ Froude's regard for Bismarck reflects that of Carlyle, who considered the chancellor as "the chiefest statesman of the age" and "the right man in the right place," a phrase Froude used in the final sentence of Letter XII. David Alec Wilson and David Wilson Mac Arthur, Carlyle in Old Age (New York: E. P. Dutton \& Co., 1934), pp. 367 and 218.

${ }_{80}$ This letter and the remainder of those to Cluseret were written on mourning stationery. Froude's second wife, Henrietta Elizabeth Warre, died on February 12, 1874 . This letter except for the last sentence was printed in the Nation, LXXIV, 505.

${ }^{31}$ Disraeli formed a new ministry in February 1874 ; he also served as First Lord of the Treasury. Others in it were: Lord Cairns (Lord Chancellor), the Duke of Richmond (Lord President), the Earl of Malmesbury (Lord Privy Seal), Richard A. Cross 
tions. The Prime Minister and the Earl of Derby ${ }^{\mathbf{2}}$ are men of large liberal sentiments. They are conscious that the world is moving and that they must move along with it. Others among the ministers, men of great ability also, are more under the influence of the Past, and are more keenly hostile to the Spirit of Democracy and revolt against established Institutions. Among these the Marquis of Salisbury ${ }^{\mathbf{3}}$ is the most prominent, - and before him as Minister for India your application would have to be laid if you present it in its present form. I need hardly tell you that the answer would be unfavourable. Your offer to serve in Africa, while generously made, was rejected by the late Liberal ministry, with immediate emphasis. The objections felt by $\mathrm{M}^{\mathrm{r}}$ Cardwell and by Lord Kimberley ${ }^{34}$ would present themselves more strongly to the Marquis of Salisbury.

The political situation of England can scarcely be intelligible to any one who is not himself an Englishman.

Forty years ago we started with enthusiasm on the career of Reform to make a new heaven and a new earth. We expected that Political Reform would bring Genius and intellect to the front and introduce a spirit of Justice into the administration of the Empire. The result has been that an aristocracy of wealth has superseded the aristocracy of birth. The higher interests of the country have been sacrificed to the men of capital; the manufacturers, the traders, the

(Home Secretary), the Earl of Derby (Foreign Secretary), the Earl of Carnarvon (Colonial Secretary), Gathorne Hardy (War Secretary), the Marquis of Salisbury (Indian Secretary), Sir Stafford Northcote (Chancellor of the Exchequer), G. Ward Hunt (First Lord of the Admiralty), and Lord John Manners (Postmaster-General).

${ }^{32}$ Froude's friend, Edward Henry Stanley, fifteenth Earl of Derby (1826-93), acted as Colonial Secretary and Indian Secretary in $1858-59$. In 1863 he was offered the crown of Greece which he refused. He was Foreign Secretary to his father and Disraeli in 1 866-68. Serving again as Foreign Secretary in Disraeli's second ministry, he did not always agree with his chief. When Disraeli ordered the fleet to the Dardanelles in January 1878 , Derby resigned. Two years later he left the Conservative Party, and then from i $882-85$ acted as Colonial Secretary to Gladstone. He later joined the Liberal Unionists and acted as their leader in the House of Lords, $1886-9 \mathrm{I}$.

${ }^{33}$ Robert Arthur Talbot Gascoyne-Cecil, third Marquis of Salisbury (1830-1903), later was Prime Minister in $1885-86$, 1886-92, I 895-1902.

${ }^{34}$ The staunch Gladstonian John Wodehouse, first Earl of Kimberley (1826-1902), was undersecretary in Aberdeen's and Palmerston's governments. In $1856-58$ he acted as Envoy-Extraordinary to Russia and in 1863 to Copenhagen in an attempt to solve the Schleswig-Holstein question. In 1864 he was made Undersecretary for India and later that year Lord-Lieutenant of Ireland. Under Gladstone, he also served as Lord Privy Seal, Colonial Secretary, and Chancellor of the Duchy of Lancaster. In i 882-86 he became Secretary for India and in 1894-95 Lord President of the Council. In Roseberry's ministry of i $894-95$, he acted as Foreign Secretary. 
Shopkeepers. Instead of a science of politics we have Political Economy which leaves every one to take care of himself, and the devil, of us all. Selfishness has taken the place of patriotism. We have less ability in Parliament, instead of more. The energy of the country has drifted into an insane craving after money. Consequently a general sense has come over us that Democracy instead of mending matters -will, if we carry it further, make them worse than they are,-and we have made a Conservative Revolution. In despair of getting any real good from the Radicals we have brought back into power the representatives of the Institutions under which we grew to be a great country, with $\mathrm{M}^{\mathrm{r}}$ D'Israeli at their head who although himself a man of the people has always foreseen the true tendencies of things and whom we now understand to have been right.

Whether these men will do any better than the others time will show. For the present the game of radicalism has been played out over Europe. Each shock of revolution has been weaker since I 792 . Castelar's failure in Spain is the last effort which will be made in that direction for a long period. ${ }^{35}$

Such at least is my opinion. The prevailing passion among mankind is now love of money, and while that continues, the greater the power of the people the greater will be the Corruption-witness America.

I was myself a Republican through the best years of my life. I have been most unwillingly awakened from my dream.

Now as to yourself. It will be useless for me to write to Lord Salisbury. If you determine on making an immediate application to the Minister I should advise you to address yourself frankly-without mentioning me or any one. You are yourself sufficiently well known to $\mathrm{M}^{\mathrm{r}}$ D'Israeli. You can tell him that you have made all the reparation in your power for the Irish affair by publishing your

${ }^{35}$ Emilio Castelar y Ripolo (1832-99) achieved fame in Spanish politics and radical journalism and in literary and historical studies. After the abdication of Amadeus, a republic was established in February 1873. In the following September the cortes made Castelar chief of executive. During his brief regime, he reorganized the army, sent additional forces against the Carlists, the cantonal insurrectionists, and the mutinous Cuban militia. He also ended persecution against the Church and the clergy and endeavored to establish a firm financial system. When extremists deserted him, Castelar resigned on January 2, 1874; the cortes was dissolved, and Marshall Serrano formed a provisional government that lasted until December, when a Bourbon monarchy under Alphonso XII was restored. 
account of it. You can say to him what you say to me and leave yourself to his candour \& consideration. You will be more likely to succeed in this way than by any indirect appeal.

There is however I think a better way, if you are in a condition to avail yourself of it. Men in power are always ready to recognize service when actually done or begun. They have there something more than words to go upon. Why should you not go yourself to Herat or Cashgar. The Native Princes will eagerly welcome you $\&$ accept your assistance, and if you prove yourself useful, in organizing their troops, the Anglo Indian politicians will soon hear of it.

I give you the best advice in my power. I do not think $M^{r} D^{\prime} I$ sraeli will at once listen to your advances, for this plain reason. He is too large minded a man to feel ill will towards you, but the Radical party are on the watch for any mistake which he may make. They would not scruple in the least to declaim against his employment of General Cluseret on every platform and in every Newspaper in the Kingdom as a proof that the sober English nation ought not to trust him. You cannot expect him to encounter such a storm on your behalf till you have done something to make yourself valued. Forgive this long letter \& believe me truly yours

\section{$\mathrm{J}$ A Froude}

That Disraeli found a place for Cluseret in the British army seems unlikely; at least Froude gives no indication of such a favor in his letters. His next letter to Cluseret in the Stanton Collection was not written until March 1876 . 